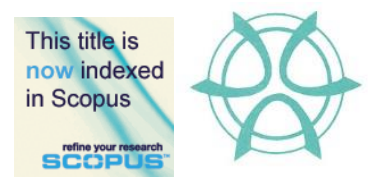

PLANNING MALAYSIA:

Journal of the Malaysian Institute of Planners

VOLUME 16 ISSUE 1 (2018), Page $63-74$

\title{
COMFORT CHARACTER OF LANDSCAPE FEATURES OF TRADITIONAL STREETS IN AMMAN, JORDAN
}

\author{
Saja Jamil Alamoush ${ }^{1}$, Nor Haslina Ja'afar ${ }^{2}$, Elina Mohd Husini ${ }^{3}$, \& \\ Wan Norisma Wan Ismail ${ }^{4}$ \\ ${ }^{1,2}$ Faculty of Engineering and Built Environment \\ UNIVERSITI KEBANGSAAN MALAYSIA \\ ${ }^{3,4}$ Faculty of Engineering and Built Environment \\ UNIVERSITI SAINS ISLAM MALAYSIA
}

\begin{abstract}
Fast expanding of urban development changes the street function and gives priority for vehicles, which effects the urban fabric and cultural life of the city. It makes walking in the street difficult and uncomfortable. Hence, this research aims to explore the influence of landscape features towards comfort character of traditional streets in Amman, Jordan. The case study was Rainbow Street in Amman, the capital city in Jordan. Mixed-method approach was used in this study, which involved direct observation (visual and behavioural) and user perception (survey and in-depth interviews) techniques. The data was analysed through thematic analyses for qualitative data and descriptive statistics for quantitative data. The results show that landscape features that contribute towards comfort character could be divided into two main categories, namely, pedestrian amenities and sidewalk. This should be taken into consideration in the design of the existing and future streets in Jordan.
\end{abstract}

Keyword: Landscape, Comfort, Character, Traditional Street, Sidewalk, Pedestrian amenities. 
Saja Jamil Alamoush, Nor Haslina Ja'afar, Elina Mohd Husini, \& Wan Norisma Wan Ismail

Comfort Character of Landscape Features of Traditional Streets in Amman, Jordan

\section{INTRODUCTION}

Streets have been described as a significant part of the urban open space that also defined as the bones of the city (Rahman, Shamsuddin, \& Ghani, 2015). Streets serve as a venue for social interaction via different types of human behaviour, including talking, playing, observing, and lingering. Streets also function as a space for families and friends and sometimes a living room or a dining room for city dwellers (Oranratmanee \& Sachakul, 2014). Thus, streets symbolize the public realm where people spend a majority of their time (Jacobs 1961; Ja'afar, Rahim, Samad, \& Rahim, 2017; Zaidin, Hussain, Tukiman, \& Shahli, 2015). According to Carr (1992), there are five major reasons why people go to public places. These are 'comfort, relaxation, passive engagement with the environment, active engagement with the environment and discovery. Rahman et al. (2015) identified comfort as the most basic of needs and the most important design criterion for a liveable street as it has a direct effect on place satisfaction.

Comfort is not just offering protection from sun, wind, and rain, but also providing a physiologically suitable setting of the street environment to support a convenient environment where various activities and outdoor culture events can occur in open public spaces (Mehta, 2006; Hajmirsadeghi, 2015). It is about providing a safe, accessible, convenient and pleasant place for people to spend their time and having their social activities (Zakaria \& Ujang, 2015). If streets are alive, secure, pleasant and exciting spaces, they can attract more people (Mehta, 2006). In this regard, the level of comfort could be determined by the length of time where people would spend in the public space (Carmona, Heath, Oc, \& Tiesdell, 2003).

At the same time landscape elements, both hard (lighting, urban furniture, paving, and public art) and soft (planting), play a significant role in creating a sense and meaning of place and affect the type of activities such as walking or sitting within the street environment. Consequently, comfort is a characteristic that should be considered when designing a convenient, safe, and friendly street environment which is one of the basic human needs in urban spaces (Carr, 1992; Jacobs, 1996; Carmona et al., 2003; Rahman et al., 2015). It influences the vitality and liveability of urban setting (Shahideh, 2013). Thus, comfort is defined as the pleasant state of physiological, psychological and physical harmony between the human body and the environment (Zakaria \& Ujang, 2015).

\section{ISSUES AND PROBLEM STATEMENT}

According to Gehl (2015), when public space became unattractive, unwelcoming and uninspiring, people will be discouraged from using it, either by enjoying its surroundings or having social activities in it. But modern urban planning pays more attention to requirements of automobiles rather than pedestrians' needs. The development of modern highways and high-rise buildings destroy the traditional urban fabric and harm urban quality (Jalaladdini \& Oktay, 2012; Ultav, Çağlar, 
PLANNING MALAYSIA

Journal of the Malaysia Institute of Planners (2018)

\& Drinkwater, 2015). Modernization adversely affected the key role played by traditional streets as a public space that enhances city appearance. When urban design focuses on motor vehicles, a lost local character must be identified (Tawil, Reicher, Ramadan, \& Jafari, 2014). Nonetheless, the previously mentioned scenario is common. In fact, it occurs at both local and global scale, which directly affects the pattern of a street or city. Al-Asad (2004) indicates that walking in Amman city has become challenging, uncomfortable, and unsafe because some streets have a problem in the continuity of good and comfort sidewalks. He adds that sidewalks in Amman were not properly maintained, as shown in (Figure 1).

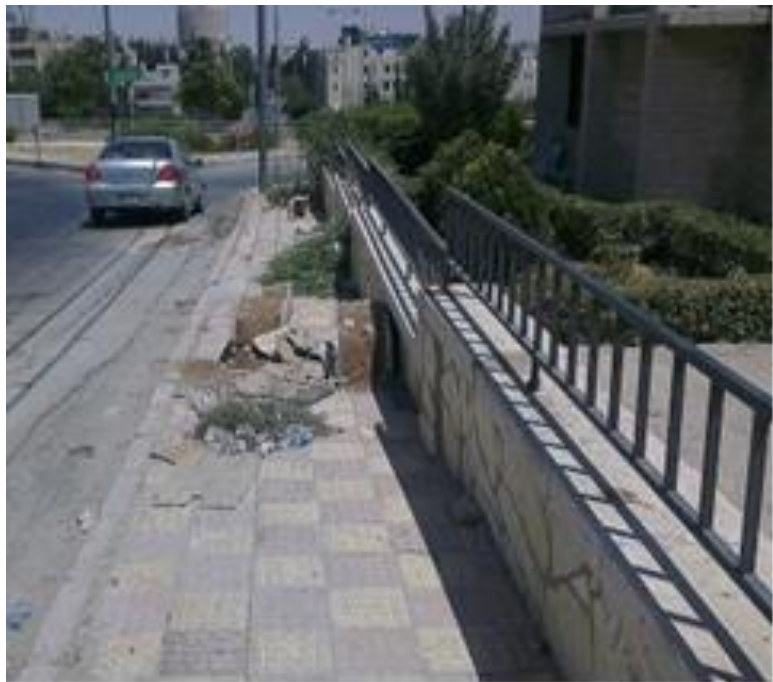

Figure 1: Example of poorly maintained sidewalk in Amman Source: Jafra News, 2015

Poor maintenance of sidewalks can also be observed in other cities in Jordan, such as Az Zarqaa. Some places have sidewalk pavements of varying heights (blocks have different levels as a result of many factors, such as rain), which affect the safety and comfort of pedestrians. Additionally, low-branching trees were planted in the middle of the sidewalks, causing difficulties to users. Sidewalks in front of markets are also used by traders to showcase their goods. All these resulted in difficulties to users and forced them to walk on the street, exposed to the danger of collision with motor vehicles. At the same time, heavy traffic also makes crossing the street as challenging and dangerous. It is, thus, important that streets are designed suitably as a social arena that gives priority to the comfort of the pedestrian. Therefore, this study aims to explore the influence of landscape features towards comfort character of traditional streets environment. 
Saja Jamil Alamoush, Nor Haslina Ja'afar, Elina Mohd Husini, \& Wan Norisma Wan Ismail

Comfort Character of Landscape Features of Traditional Streets in Amman, Jordan

\section{METHODOLOGY}

This study examines the physical elements that contribute towards comfort in traditional street. As a case study, Rainbow Street, Jordan was selected (Figure 2). Street in traditional ambience was selected because according to scholars, the sense of place by its culture, local need and appearance could be felt. This is what makes a place or town is different from another town (Shamsuddin, Sulaiman, \& Amat, 2012). Rainbow Street is located at the central location between east and west Amman, the capital of Jordan. It is well connected to the downtown area through magnificent steps. The street reveals a rich history and cultural heritage of the city of Amman; it represents a "distinctive Amman character" through its distinctive building. This street receives a high concentration of visitors and pedestrians from different ages and background, locals and foreigners due to its special location, mixed-use activities heritage and various activities (Turath Architecture \& Urban Design Consultants, 2010).

This study adopted a mixed-method approach, where field studies, qualitative method and quantitative method were used. The main techniques that were used in this study were questionnaire survey, field observation (visual and behavioural surveys), in-depth interviews, and literature and document analysis.

The questionnaire survey was conducted on 330 street users who were categorized under two types of users: (i) static users - those who are permanently tied to the study area (shop owners, traders, officers, residents) along the street (ii) mobile users - those who do not live within the study area (shoppers and tourists). In-depth interviews were conducted on 21 street users. Thematic analysis using NVIVO 10 was undertaken for qualitative data and descriptive statistics using SPSS 22 were used for quantitative data.

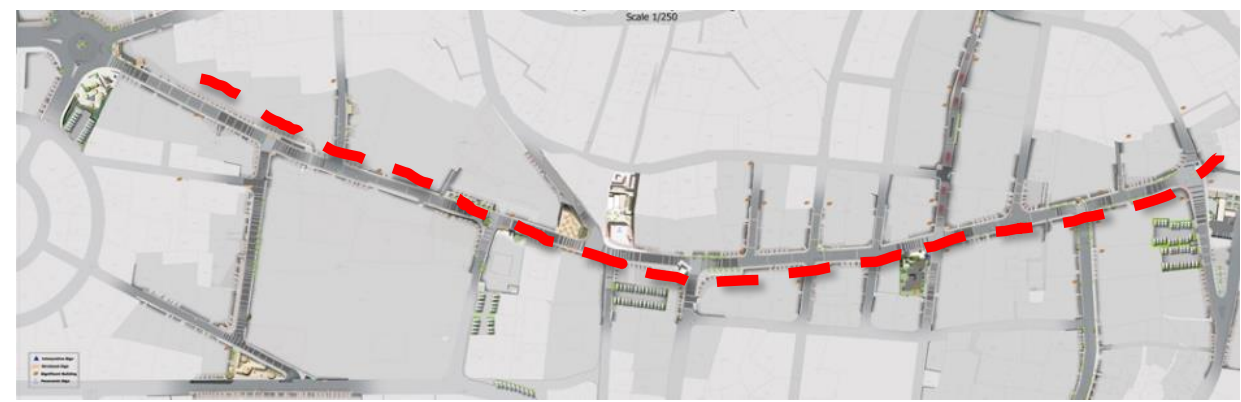

Figure 2: Rainbow Street, Amman

Source: Turath Architecture \& Urban Design Consultants, 2010 
PLANNING MALAYSIA

Journal of the Malaysia Institute of Planners (2018)

\section{RESULTS AND DISCUSSION}

The result of the analysis shows that landscape features influence users' feeling of comfort while walking along the Rainbow Street through (i) pedestrian amenities and (ii) sidewalk (Table 1).

Table 1: Landscape elements that contribute towards comfort character

\begin{tabular}{lcccccc}
\hline Element & \multicolumn{3}{c}{ Interview } & Survey & Visual \\
& Yes No & $\mathbf{\Sigma}$ & $\mathbf{N = 3 3 0}$ & survey \\
\hline $\begin{array}{l}\text { 1- Pedestrian amenities } \\
\quad \text { Public toilet }\end{array}$ & 18 & 3 & 21 & & $/$ \\
$\quad$ Seating & 21 & 21 & - & $175(53 \%)$ & $/$ \\
2- Sidewalk & 20 & 1 & 21 & & $194(58 \%)$ & $/$ \\
\hline Source: Field work & & & & &
\end{tabular}

\section{Pedestrian amenities}

\section{Public Toilet}

Clean and accessible public toilets are essential in urban public spaces (Ja'afar, Sulaiman, \& Shamsuddin, 2012; Askari, Soltani, \& Mohd, 2015) because urban public spaces must function as outdoor living room where users can fulfil their needs such as going to the toilet to ensure their comfort (Speck, 2013). According to the interviews, 18 respondents insisted on the importance of public toilet provision, and keeping it clean and well maintained, as this can contribute to the attraction and comfort of visitors to a street.

Based on observation, Rainbow Street lacks public toilet. Therefore, the provision of clean and well-maintained public toilets must be taken into consideration in improving the comfort character of Rainbow Street $s$ well as in designing new streets so that they can attract visitors and prolong their stay in the areas.

\section{Seating}

Proper placement of seating in activity areas creates a sense of place, comfort, enjoyment and successful urban area. The results of the survey show that $53 \%$ of the respondents feel comfortable with the seating provided in the study area. However, some of the respondents said there should be more seating in such crowded street. All of the respondents in the interview $(n=21)$ mentioned that they like to sit and watch the street activity and the panoramic view. 
Saja Jamil Alamoush, Nor Haslina Ja'afar, Elina Mohd Husini, \& Wan Norisma Wan Ismail

Comfort Character of Landscape Features of Traditional Streets in Amman, Jordan

\section{"I like sitting on the side benches with my friend and having our sandwiches} from Al-Quds cafeteria watching people." R13 street user.

The quotation above indicates that the users enjoy sitting on the street benches and watching the street activity, socializing, and having their snacks. Public seating should be oriented toward interest points such as panoramic view, water view, open spaces, or the street itself if it is lively and perpendicular to the curb.

Meanwhile the visual survey (as shown in Figure 3) found that benches along the street have different shapes and designs that meet users' needs. Their placement is also concentrated in areas with more activities. However, shades in the seating areas is required to ensure users' comfort. Public seating should be comfortable, shaded and with different shapes that provide comfortable and active environment where people can rest, socialize, or eat and enjoying public space (Latip, 2011; Austin, 2002; Hajmirsadeghi, 2015). 
PLANNING MALAYSIA

Journal of the Malaysia Institute of Planners (2018)

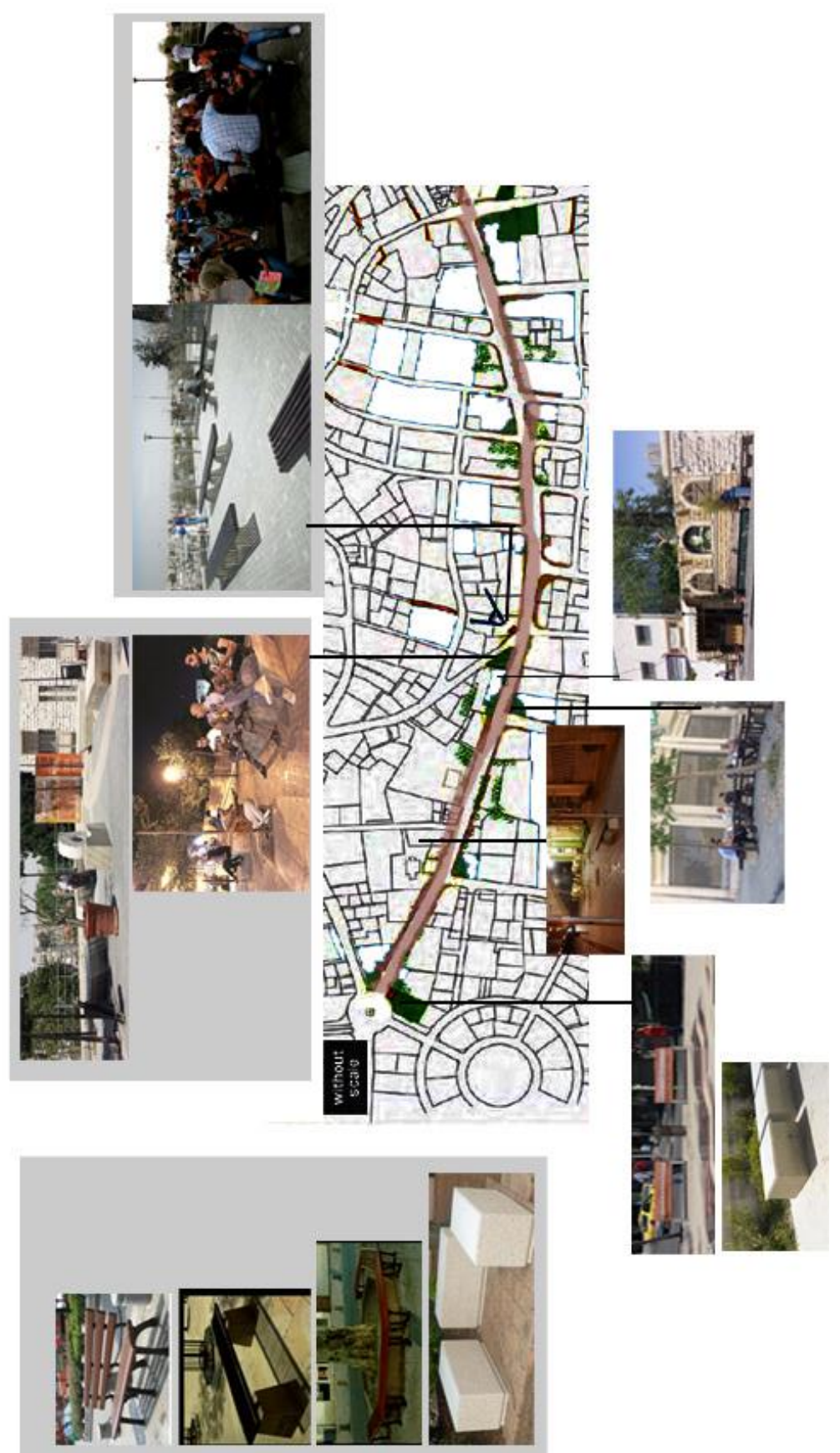

Figure 3: Location and types of seating on Rainbow Street Source: Fieldwork 
Saja Jamil Alamoush, Nor Haslina Ja'afar, Elina Mohd Husini, \& Wan Norisma Wan Ismail

Comfort Character of Landscape Features of Traditional Streets in Amman, Jordan

\section{Pathway type \& Pavement}

The survey showed that $58 \%$ of respondents were satisfied with the sidewalk condition in the study area, and they feel comfortable while walking on the sidewalk as it was non slippery, free of obstacle most of the time and with a suitable width. Meanwhile, 14 respondents mentioned that they feel comfortable when using the sidewalk as it connects continuously the parking area to their destinations. Even when users were forced to walk on the road due to crowded sidewalk, they still feel safe because the design of the road forces the cars to reduce their speed.

"We can use the sidewalk most of the time. Its width is ok, but when the street is crowded it's hard to walk in, so we need to use the vehicle path. It's still okay as the street design is for pedestrian, and its rough pavement and narrow width force the cars to slow down." R15 street user

The concept of "Traffic Calming" was applied in the design of the streets, thus reducing the speed of vehicle and increase safety to non-motorized users like pedestrians and cyclists, therefore guaranteed comfort environment for the street users (García, Torres, Romero, \& Moreno, 2011; Yousif, Alterawi, \& Henson, 2013; Karndacharuk, Wilson, \& Dunn, 2014; Panchal, Khan, Sharma, Bharti, \& Singh, 2017; Grey, Siddall, \& O'Shea, 2011). At the same time, the use of suitable non-slippery pavement material for the sidewalk also contributes in enhancing the comfort of the users (Figure 4). 
Journal of the Malaysia Institute of Planners (2018)

(i)

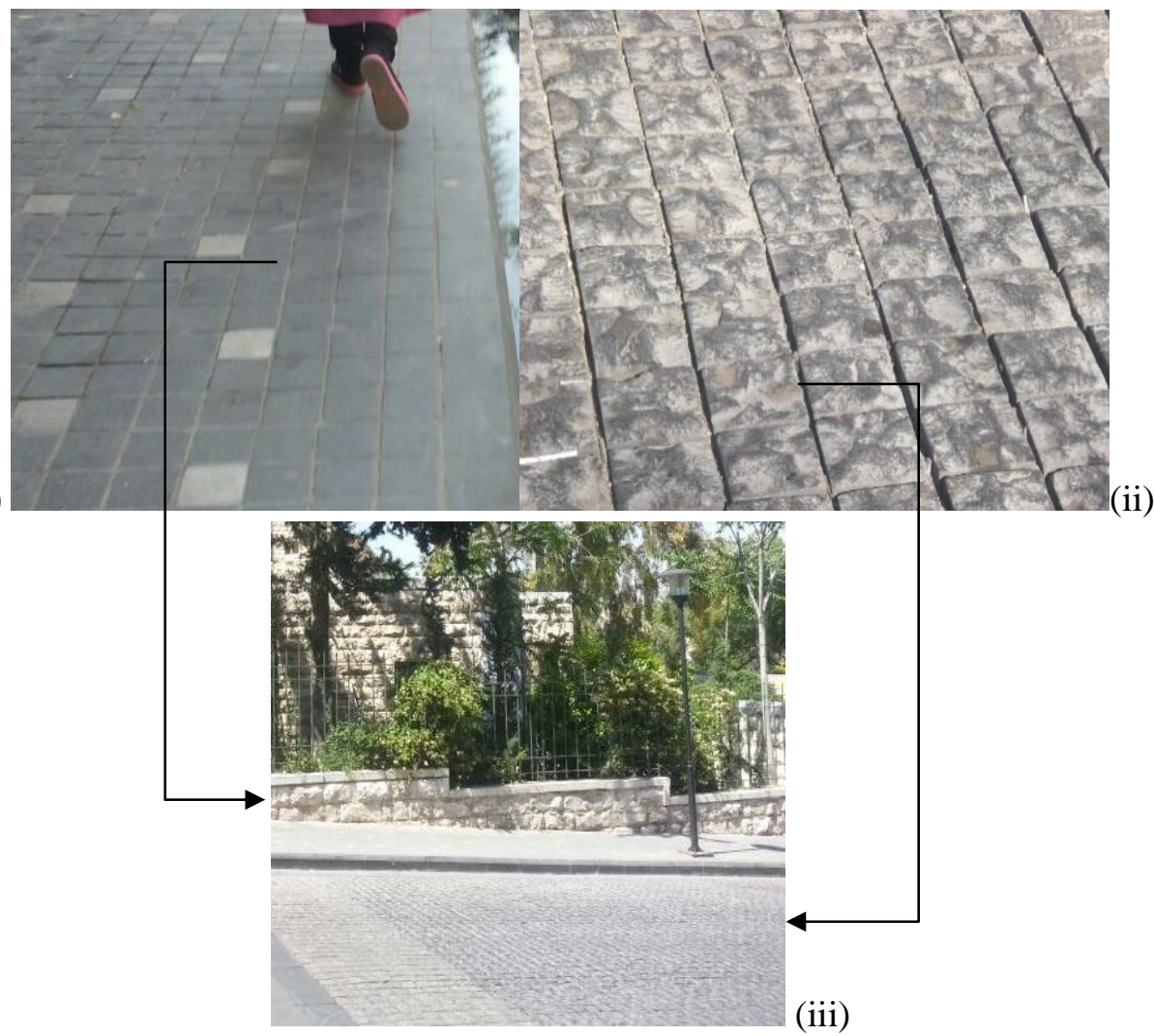

Figure 4: Sidewalk pavement of Bazalt Stone, cut finish) (i) and road pavement of Bazalt Stone, light hammered finish (ii) being used at Rainbow Street (iii) Source: Fieldwork

(i)

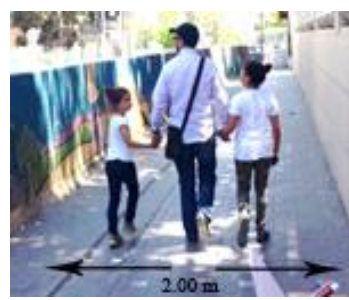

(ii)

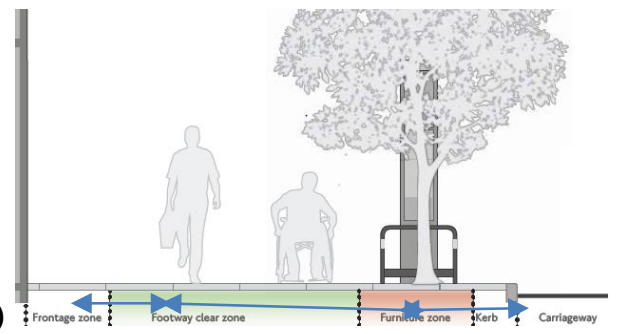

Figure 5: (i) Example of Sidewalk in Rainbow Street; (ii) Sidewalk Divisions Source:(i) Field work, (ii)(Rice,2017)

Visual survey also confirmed that the sidewalk is continuous, free of obstacles such as tree and lamp post, and with sufficient width, which ranges between $1.5 \mathrm{~m}$ to $2 \mathrm{~m}$ (Figure 5). The width of the sidewalk meets the dimension 
Saja Jamil Alamoush, Nor Haslina Ja'afar, Elina Mohd Husini, \& Wan Norisma Wan Ismail

Comfort Character of Landscape Features of Traditional Streets in Amman, Jordan

suggested by many parties. For instance, Keat, Yaacob and Hashim (2016) suggest that sidewalk width should be between $1.8 \mathrm{~m}$ to $3 \mathrm{~m}$. Meanwhile, Brezina, Graser and Leth suggest that it should not be less than $1.5 \mathrm{~m}$. Sidewalk with sufficient width would allow at least two people to walk comfortably side by side or in opposite direction, and also would allow wheelchair users to move conveniently. Wheelchair users require $1.5 \mathrm{~m}$ width to turn around and $1.8 \mathrm{~m}$ to pass other wheelchair users (Boodlal, 2004; Ja'afar, Sulaiman, \& Shamsuddin, 2015; Ja' afar et al., 2017; Grey et al., 2011). Walking zone should be straight and continuous and free of all obstacle to allow people to walk in the most direct route possible. Meeting these requirements will ensure comfort, pleasant and safe environment for street users (Tariq, 2007)

\section{CONCLUSION}

Feeling comfort is one of the main reason why people use or go to the public spaces such as street, in addition, comfort is main criteria for the success of streets. At the same time, the landscape features are significant aspects that constitute the street. Accordingly, the purpose of this research is to determine the landscape features that contribute towards comfort while walking in the street in Jordan context, in this research it was revealed that the landscape features that contribute to comfort while walking in the street in Jordan context were mostly similar with the previous theories. The study shows, the landscape features that contribute to the comfort are (a) pedestrian amenities (public toilet and seating), (b) pathway type and pavement. This recognizes the factors that need to be considered in future guidelines and policies for planning and designing new street as a guide to create a comfortable street environment for the pedestrian that is lacking in new streets at present.

a. The design of the pedestrian sidewalk with a minimum size $(1.8 \mathrm{~m})$.

b. The sidewalk must be free from any holes or obstacles to ensure the safety of the pedestrians

c. Using traffic calming techniques in designing the vehicle's path that reducing vehicle speed and improve street safety.

d. Reduction of vehicular space to provide for the footpath, cycle lane.

\section{ACKNOWLEDGEMENT}

We acknowledge the Faculty of Engineering and Built Environment at Universiti Kebangsaan Malaysia (UKM) for supporting this research under Fundamental Research Grant Scheme project (FRGS/1/2015/SSI11/UKM/02/2). 


\section{REFERENCES}

Al-Asad, M. (2004, June 24). Sidewalks of Amman. The Jordan Times. Retrieved from http://www.csbe.org/e-publications-resources/urban-crossroads/sidewalks-ofamman/

Askari, A. H., Soltani, S., \& Mohd, I. (2015). Engagement in public open spaces across age groups: The case of Merdeka Square in Kuala Lumpur city, Malaysia. Urban Design International, 20(2), 93-106.

Austin, E. K. (2002). The social bond and place: A study of how the bureau of land management contributes to civil society. Administrative Theory \& Praxis, 24(2), $355-362$.

Boodlal, L. (2004). Accessible sidewalks and street crossings - An informational guide.

Brezina, T., Graser, A., \& Leth, U. (2017). Geometric methods for estimating representative sidewalk widths applied to Vienna's streetscape surfaces database. Journal of Geographical Systems, 19(2), 157-174.

Carmona, M., Heath, T., Oc, T., \& Tiesdell, S. (2003) Public places, urban spaces: The dimensions of urban design. Amsterdam: Architectural Press.

Carr, S. (1992). Public space. Cambridge: Cambridge University Press.

García, A., Torres, A. J., Romero, M. A., \& Moreno, A. T. (2011). Traffic microsimulation study to evaluate the effect of type and spacing of traffic calming devices on capacity. Procedia-Social and Behavioral Sciences, 16, 27028

Gehl, J. (2015, December 18). In search of the human scale [Video File]. Retrieved from https://www.youtube.com/watch? $=\mathrm{Cgw} 9 \mathrm{oHDfJ} 4 \mathrm{k} \& \mathrm{t}=530 \mathrm{~s}$

Grey, T., Siddall, E., \& O’Shea, E. (2011). Shared space, shared surfaces and home zones from a universal design approach for the urban environment in Ireland.

Hajmirsadeghi, R. S. (2015). Design factors that influence the effective use of Meydan in Iran (Doctorate dissertation). Universiti Teknologi Malaysia, Malaysia.

Ja'afar, N. H., Sulaiman, A. B., \& Shamsuddin, S. (2012). The contribution of landscape features on traditional streets in Malaysia. Procedia-Social and Behavioral Sciences, 50, 643-656.

Ja'afar, N. H., Sulaiman, A. B., \& Shamsuddin, S. (2015). Karakter fizikal jalan tradisional: Kajian kes di Melaka, Malaysia. Universiti Teknologi Malaysia.

Ja'afar, N. H., Rahim, A. A., Samad, N. A. A., \& Rahim, C. R. C. (2017). Sidewalk accessibility at Melaka's traditional streets for people with disabilities (PWDs). Planning Malaysia Journal, 15(1), 389-396.

Jacobs, J. (1961). The death and life of great American cities. New York, NY: Random House.

Jafra News. (2015, May 6) عطاءات بمليون ومائة الف دينار لإنشاء وصيانة ارصفة في العاصمة/Ww/.j. Retrieved from http://www.jfranews.com.jo/XnkiR/more-110847.

Jalaladdini, S., \& Oktay, D. (2012). Urban public spaces and vitality: a socio-spatial analysis in the streets of Cypriot towns. Procedia-Social and Behavioral Sciences, 35, 664-674.

Karndacharuk, A., Wilson, D. J., \& Dunn, R. (2014). A review of the evolution of shared (street) space concepts in urban environments. Transport reviews, 34(2), 190220. 
Saja Jamil Alamoush, Nor Haslina Ja'afar, Elina Mohd Husini, \& Wan Norisma Wan Ismail

Comfort Character of Landscape Features of Traditional Streets in Amman, Jordan

Keat, L. K., Yaacob, N. M., \& Hashim, N. R. (2016). Campus walkability in Malaysian public universities: A case-study of Universiti Malaya. Planning Malaysia Journal, Special Issue 5, 101-114.

Latip, N. S. A. (2011). Contextual integration in waterfront development (Doctoral dissertation). University of Nottingham, U.K.

Mehta, V. (2006). Lively Streets: Exploring the relationship between built environment and social behavior (Doctoral dissertation). University of Maryland, Washington, USA.

Oranratmanee, R., \& Sachakul, V. (2014). Streets as public spaces in Southeast Asia: Case studies of Thai pedestrian streets. Journal of Urban Design, 19(2), 211229

Panchal, S., Khan, M. M., Sharma, A., Bharti, A. A., \& Singh, B. (2017). Effectiveness of traffic calming devices on speed characteristics of road user. International Journal of Theoretical And Applied Mechanics, 12(1), 167-190.

Rahman, N. A., Shamsuddin, S., \& Ghani, I. (2015). What makes people use the street? Towards a liveable urban environment in Kuala Lumpur city centre. ProcediaSocial and Behavioral Sciences, 170, 624-632.

Shahideh, S. (2013). Analyzing the quality of pedestrian street in the case of Istiklal Street in walled city of Famagusta (Doctoral dissertation). Eastern Mediterranean University - Doğu Akdeniz Üniversitesi.

Shamsuddin, S., Sulaiman, A. B., \& Amat, R. C. (2012). Urban landscape factors that influenced the character of George Town, Penang UNESCO World Heritage Site. Procedia-Social and Behavioral Sciences, 50, 238-253.

Speck, J. (2013). Walkable city: How downtown can save America, one step at a time. New York: North Point Press, a division of Farrar, Straus and Giroux.

Tariq, M. M. (2007). Livable streetscape: Creating a pedestrian network in the town of Morden, Monitoba (Master's thesis), University of Manitoba, Winnipeg, Canada.

Tawil, M., Reicher, C., Ramadan, K.Z., \& Jafari, M. (2014). Towards more pedestrian friendly streets in Jordan: The case of Al Medina Street in Amman. Journal of Sustainable Development, 7(2), 144-158.

Turath Architecture \& Urban Design Consultants (2010). Aga Khan Award for Architecture: Architect's Record - Rainbow Street Urban Regeneration Project. Retrieved from https://archnet.org/system/publications/ contents/2264/original/FLS2641.pdf?1384758460

Ultav, Z. T., Çağlar, T. N., \& Drinkwater, S. B. D. (2016). Architectural literary analysis: Reading "The death of the Street" through Ballard's literature and Trancik's "Lost Space". METU Journal of the Faculty of Architecture, 32(2), 133-150.

Yousif, S., Alterawi, M., \& Henson, R. R. (2012). Effect of road narrowing on junction capacity using microsimulation. Journal of Transportation Engineering, 139(6), 574-584.

Zaidin, N., Hussain, M. R. M., Tukiman, I., \& Shahli, F. M. (2015). Place attachment in relation to urban street vitality. American Transactions on Engineering \& Applied Sciences, 4(4), 219-230.

Zakaria, J., \& Ujang, N. (2015). Comfort of walking in the city center of Kuala Lumpur. Procedia-Social and Behavioral Sciences, 170, 642-652. 